\title{
Subject-matter Jurisdiction of Courts of First Instance in the Jordanian Judicial System
}

\author{
Dr. Fahad Yousef al-kasassbeh, \\ Associate Professor of Criminal Law, Amman Arab University, Dr.fahadalkasassbeh@yahoo.com, \\ Amman Arab University, Amman _ Jordan
}

\begin{abstract}
It is established that the jurisdictional rules are binding legal rules. The parties to whom provisions of these rules apply are required to comply with them, since the binding nature of rules of subject-matter jurisdiction oblige the parties to the proceedings, whether plaintiff or defendant, to adhere to them. Further, the public prosecutor's office and courts are required to comply with these rules. If a court finds that it does not have jurisdiction over a case or a complaint filed before it, then it should declare lack of jurisdiction. It is established that rules of subject-matter jurisdiction are part of the public order. This is since the legislator determines such jurisdiction for a public interest, i.e. the justice. Hence, violating the rules of subject-matter jurisdiction results in absolute invalidity.

This study aims to identify the subject-matter jurisdiction of the court of first instance without dealing with the territorial jurisdiction. This is in view of the problems that the subject-matter jurisdiction raises, especially with the large number of amendments made to the legislations that define this jurisdiction without the knowledge of the relevant parties, which raises a kind of confusion and ambiguity. The nature of subject-matter jurisdiction is defined in the introductory topic of this study. The subject-matter jurisdiction of the court of first instance over civil matters and criminal matters is defined in three topics. The study ends with the most important findings and recommendations, including, but not limited to, the special courts are cancelled and their jurisdiction is transferred to the courts of first instance.
\end{abstract}

Keywords:

Subject-matter Jurisdiction, Courts , Jordanian Judicial, System , court

Article Received: 18 August 2020, Revised: 3 November 2020, Accepted: 24 November 2020

\section{Introduction:}

In the modern states, it is established that the sovereignty resides in nation or the people, and that such sovereignty is exercised through three aspects: legislation, enforcement, and the judiciary. The constitutions usually seek to provide for the independence of the judiciary within the scope of the general principle "separation of powers". This principle requires separation of the three powers in terms of the exercise of the function, and does not prevent their cooperation in the way of achieving their functions.

The judicial power uses individuals and judicial bodies called courts. These individuals -members of those bodies- are independent and impartial specialists and only governed, when delivering judgments, by their conscience and the law. These courts are classified or divided into different divisions according to the aspect from which they are viewed. The Jordanian constitution divides the courts into three types: civil, religious, and special. The civil courts have a general mandate. The jurisdiction of religious and special courts is an exception to such general mandate, "Articles 99-101 of the Jordanian Constitution."

The civil courts include the magistrate courts, the courts of first instance, the courts of appeal, the court of cassation and the supreme court of justice. 
This paper deals with the jurisdictional rules that define the provisions of subject-matter jurisdiction of the courts of first instance. This study is divided into three topics:

Introductory topic: definition of the phrase subject-matter jurisdiction of the courts of first instance as a type of civil jurisdiction.

Topic 1: courts of first instance have original jurisdiction in the Jordanian judicial system.

Topic 2: jurisdiction of courts of first instance over the summary matters and challenges to subject-matter jurisdiction

\section{Problem of the Study:}

The court of first instance is considered the basic unit of the Jordanian judicial system, as it has comprehensive and general mandate and jurisdiction over civil and criminal disputes. The promulgation of legislations that determine the jurisdiction, as recently amended, such as the Magistrate's Courts Law, the Civil Courts Formation Law, and the Enforcement Law, has diminished the role of the court of first instance and reduced many of its powers, especially with the introduction of amendments to these legislations.

The problem that has arisen in this regard is that some of the parties to the proceedings, litigants, and even the public prosecution's office and the courts did not keep pace with these amendments. This caused a problem when filing some cases and complaints before the court of first instance, even though hearing such cases and complaints has been vested in the magistrate courts or other special courts. Hence, this study seeks to address this problem and explain subject-matter jurisdiction of the court of first instance, according to the latest amendments, in order to avoid conflicts of jurisdiction.

\section{Methodology of the Study:}

In this study, the descriptive analytics method is used. This method describes the provisions mentioned in the Magistrate Courts Law No. 23 of 2017, Civil Courts Formation Law No. 30 of 2017, and the Criminal Procedure Law No. 32 of 2017 by examining the amendments contained therein regarding the subject-matter jurisdiction of the courts of first instance in their civil and criminal capacity, and analyzing these provisions thoroughly in accordance with the latest legislative amendments.

\section{Introductory Topic}

Definition of the phrase subject-matter jurisdiction of the courts of first instance as a type of civil jurisdiction

This introductory topic includes the following requirements:

\section{Requirement 1: Definition of civil jurisdiction}

The judiciary is one of the manifestations of the state's sovereignty that it exercises over its territory and over those residing in such territory. This exercise is called the court's jurisdiction over disputes. We should differentiate between the court's jurisdiction over disputes and the laws applied by such court to these disputes.

The jurisdiction of a court is its power and mandate over certain disputes determined by the law. Three elements must be available in jurisdiction: 1. A court or a judicial body, 2. A court has the power to hear and rule, and 3. A case is filed to the court.

Hence, the jurisdiction can be defined as "the mandate and power of judicial bodies in particular to grant judicial protection in accordance with the legal terminology. It is also the share of judicial bodies and courts in disputes and matters over which they have jurisdiction and authority to grant judicial protection.

It can also be defined as "the authority or jurisdiction of a court or judicial body to examine and rule in a case" and it is "a function or authority to determine the presence or absence of 
rights". It is the function or the power that is "granted by law to a certain entity" and this entity may be a court or a judicial or non-judicial body, and the determination of the right may be in the form of issuing an order for action or omission, or in the form of recognizing the existence of a right, and a dispute may exist or not.

Jurisdiction of civil courts is divided into: 1 . Functional jurisdiction, 2. Subject-matter jurisdiction, 3. Case-value jurisdiction and 4. Territorial jurisdiction. This means that jurisdiction of civil courts can be viewed in terms of:

1- The courts that have jurisdiction over all people residing on the state's territory. This is called the national jurisdiction. These rules determine part of jurisdiction assigned to each judicial body, i.e. distribution of jurisdiction to these bodies, where the lawsuit is determined to be examined by the administrative, civil or religious courts.

2- The geographical area governed by the court's jurisdiction within the state. This is called territorial jurisdiction of the court. Accordingly, the courts of the same class that have the power to adjudicate the dispute are determined. The law provides for the formation of magistrate courts or courts of first instance to be distributed to governorates and departments of the Kingdom. In these governorates, the law provides for existence of "a magistrate" court or a magistrate court and a court of first instance. The law grants them the power to adjudicate disputes arising within their jurisdiction.

3- Nature of disputes in the scope of the state. Here, we determine types of disputes, where there is a subject-matter jurisdiction for each national judicial body. These rules determine the competent court from among the courts of the same degree according to the type, subject-matter of nature of the lawsuit, regardless of its value.

4- Value of dispute- if the value of dispute is law, then such dispute is examined by a certain court. However, if the value of dispute is higher, then such dispute is examined by another court. According to this jurisdiction, the lawsuits are distributed according to the value of lawsuit upon which the exclusive court that has jurisdiction over the lawsuit is determined.

Article 3 of the Magistrate Courts Law No. 15 of 1952, as amended, as well as the Law No. 23 of 2017 provides that, the magistrate judge may examine:

1. The civil cases whose subject-matter is a debt, movables or immovable provided the claimed amount is not more than ten thousand JOD".

Hence, if the value of the lawsuit is 10 thousand JOD or less, then such lawsuit is examined by the magistrate courts. Yet, if the value exceeds such amount, then it is examined by the courts of first instance. This limit is called the limit of case-value jurisdiction.

\section{Requirement 2: Definition of the subject- matter jurisdiction of courts of first instance}

The subject-matter jurisdiction of courts means that each of the three types of courts (civil, religious and special) examines certain lawsuits (under the law). The subject-matter jurisdiction of civil courts means each type of civil courts has jurisdiction over certain lawsuits. The magistrate courts have an exclusive jurisdiction over the lawsuits determined under the Magistrate Court Law. Other lawsuits fall under jurisdiction of the courts of first instance, unless otherwise set out under the law. The courts of appeal have jurisdiction over the appeals submitted against the decisions that may be appealable before such 
courts after being delivered by the magistrate courts and courts of first instance. The court of cassation has jurisdiction over the appeals against the decision issued by the courts of appeal as provided under the law.

Technically speaking, the subject-matter jurisdiction means the courts' power to adjudicate disputes according to their type and nature. The criterion for determining jurisdiction of courts is the nature of legal relation, the subject-matter of protection, regardless of its value, as determined under the law. When the law provides for the court's subject-matter jurisdiction over a certain lawsuit, then the value of such lawsuit is ignored. What matters here is examination of the filed lawsuit to know whether it falls under jurisdiction of the court as set out in the law.

The court is the body that examines nature of the dispute in order to determine the issue of jurisdiction. This examination could be positive leading to granting such court the jurisdiction over the dispute. However, the court could find that the examination does not define nature of dispute. Hence, defining the jurisdiction by the court based on the subject-matter criterion is a kind of independence for determining its own jurisdiction.

In terms of subject-matter, the court of first instance examines and adjudicates cases that do not fall within the jurisdiction of another court under any effective law. Article 30 of the Jordanian Civil Procedure Law No. 24 of 1988 amended by Law No. 31 of 2017 provides that "the court of first instance shall examine and adjudicate cases that do not fall within the jurisdiction of another court upon any valid law. It shall also examine and adjudicate the summary requests and all the other matters in relation with the original request no matter of which amount and type they shall be".

Thus, everyone can initially resort to the court of first instance since it has jurisdiction over lawsuits that do not fall within jurisdiction of any other court in Jordan. In other words, the law determines the lawsuits that fall within jurisdiction of all courts, other than the court of first instance.

After Article 30 of the Civil Procedure Law was amended by Law No. 31 of 2017, there is no room to say that justice is denied since the court of first instance has jurisdiction over any lawsuit for which the law does not provide for jurisdiction of a certain court.

Some laws provide that certain lawsuits fall exclusively within jurisdiction of the court of first instance. For example, the court of first instance can examine cases of personal status between a party from a non-Muslim religious community and a party from a Muslim community unless the parties agree to accept the authority of the Sharia courts. Further, the court of first instance has jurisdiction over the personal status cases between non-Muslims who do not belong to one sect. "Article 7 of the Christian Communities Council Law No. 28 of 2014."

The court of first instance was used to examine decisions on rejecting applications for nomination, according to Article 13 / c of the Election Law No. 34/2001 and its decisions were final. However, this Article was amended under Article 15/2 of the Election Law No. 6 of 2016 where the court of appeal became the body that has jurisdiction over this issue.

Moreover, the court of first instance examines the requests for enforcement of foreign judgments pursuant to the Foreign Judgment Enforcement Law No. 8 of 1952. Article 4 of the said Law provides that "the case for requesting enforcement of foreign judgment shall be filed before the court of first instance in which jurisdiction the convict resides or the court within its jurisdiction property of the convict exists if he does not reside in the Hashemite Kingdom of Jordan".

Further, the court of first instance examines and adjudicates the summary requests and all the other 
matters in relation with the original request no matter of which amount and type they shall be (Article 30 of the Civil Procedure Law). It should be mentioned here that the jurisdiction of the court is not confined to adjudicating the summary matters; rather it extends to include the matters in connection with them regardless of their value of type. In this regard, the Egyptian Court of Cassation ruled that " it is established in the court of cassation that if the court of first instance has jurisdiction over a certain request, then such jurisdiction shall extend to any other associated requests even if they fall within the subject-matter jurisdiction of the magistrate, where the jurisdiction over the entire lawsuit is established to the court of first instance".

It goes without saying that the summary requests or matters are stipulated in Article 32 of the Civil Procedure Law, which provides that: On an interim basis, the summary matters judge will examine the claims, without causing any prejudice to the following matters. However, this shall not prevent the trial court to examine such matters if submitted to it on a hierarchical basis:

1- Urgent matters that are under the risk of time lapse without being adjudicated.

2- Considering the applications to appoint an agent or guardian of property or precautionary sequestration; custody or travel ban.

3- A prompt inspection to prove a certain case.

4- Calling for a witness with the fear of not hearing him in a timely manner to decide on a topic that has not been submitted to the judiciary yet and it is possible to be submitted to it. All the incurred expenses shall be borne by the requester".

In this respect, the Jordanian Court of Cassation ruled that "Article 102 of the Constitution shows that the civil courts have jurisdiction over is all civil disputes, whether the government is a party to it or not, in the sense that there is a judge for every lawsuit taking into account that it is permissible under this constitution or any other legislation to delegate the right of jurisdiction to a religious or special court. However, no one is prevented from right to litigation before civil, religious or special courts. What is mentioned in Article 103 of the Constitution means the manner in which the civil courts exercise their right to a judicial or criminal justice and not to exclude some of the disputes from their right to litigation".

Topic 1: courts of first instance have original jurisdiction in the Jordanian judicial system.

This topic is divided into two requirements:

\section{Requirement 1: jurisdiction of the court of first instance, in its first instance capacity}

The courts of first instance are the basic cell of the courts of the first degree in the Jordanian judicial system. Under this system, the courts of first instance have comprehensive general jurisdiction over disputes in the Jordanian judiciary so that they can examine all disputes including, without limitation, civil and criminal matters unless the law otherwise provides.

Accordingly, Article (4/1) of the Jordanian Civil Court Formation Law No. (17) of 2001, as amended, and Law No. 30 of 2017 provides that: " courts called (Courts of First Instance) shall be formed in the governorates or districts ,,, and they shall have jurisdiction over all civil and criminal cases unless such jurisdiction is delegated to any other court". Further, Article (30) of the Jordanian Civil Procedure Law as amended by Law No. 14 of 2001, provides that: "The Court of First Instance shall hear and adjudicate cases that do not fall within the jurisdiction of another court under any effective law in effect ...".

In its criminal capacity, the court of first instance has jurisdiction over all misdemeanors referred to it by the attorney-general, or his delegate, that do not fall within the jurisdiction of the magistrate courts. Also, it has jurisdiction over all felonies 
and the misdemeanors associated with felonies referred to it upon the indictment. It should be also noted that no person is brought to the court of first instance for the offenses that cannot be examined by the magistrates, unless the attorneygeneral issues a potential indictment for trial as to such offense.

The court of first instance also has jurisdiction over non-estimable lawsuits, since the legislator assumes that that value of such lawsuits exceeds limit of magistrate jurisdiction. Indeed, this is a subject-matter jurisdiction, and it is not appropriate to call it case-value jurisdiction. In fact, value of a lawsuit can be estimated. Such jurisdiction extends powers of the courts of first instance and supports its capacity as a general jurisdiction.

\section{Powers of the court of first instance include:}

\section{Bankruptcy lawsuits}

This power is covered by Articles (290 317) of the Jordanian Trade Law No. 12 of 1966.

The first instance court that decides to declare bankruptcy can examine all disputes in connection with such bankruptcy, including those arising out of declaration of bankruptcy or management of bankruptcy or whose determination requires applying a rule of bankruptcy mentioned in the Trade Law whether filed by or against the receiver in bankruptcy, the creditor, or others.

2. Restriction of freedom of insolvent debtor lawsuits

This is covered by the provisions of Article (2) of the Insolvency Law No. 21 of 2018, and these lawsuits brought against everyone other than traders.

The court of first instance in which jurisdiction the debtor resides is the body that tries these lawsuits.

Articles from (375-382) of the Civil Law No. 43 of 1976 clarify the procedures for restricting freedom of insolvent debtor as well as the court's power to hear all disputes related to insolvency, which are those arising from the decision of restriction (i.e. insolvency declaration) or the determination of which requires the application of one of the insolvency rules stipulated in the Civil Law.

\section{Preemption Lawsuits}

In accordance with Article (1150) of the Jordanian Civil Law, preemption means "the right to own the sold property or part of it, even if the buyer is forced to do so provided that his is paid the incurred price and expense".

Like the precedence lawsuit, a preemption lawsuit is initiated before the Court of First Instance, within whose jurisdiction the sold property exists.

\section{Precedence Lawsuits}

These lawsuits are filed for the right of disposition of the state lands. The right of preference corresponds to the right of preemption concerning the owned immovable property, with some differences. The right of disposition is required to be formally sold before the notary public in accordance with Article (1169) of the Civil Code in order to be proven.

The preference lawsuit is filed before the court of first instance within whose jurisdiction the state land exists pursuant to Article 2 of the Law No. 51 of 1968 amending the provisions in connection with immovable property.

5. The lawsuit for correcting the name recorded in an official register, other than for civil status registers:

An example of this is records of land register in the Lands and Survey Department, where errors due to a clerical oversight are examined by the Lands and Survey Department. On the other hand, other data errors or legal errors are examined by the courts of first instance in 
accordance with Article 16/6 of the Land and Water Settlement Law No. 40 of 1952. In this regard the Jordanian Court of Cassation ruled that "it is established in jurisprudence that correction of a name recorded in land register for which settlement has been made due to a clerical error is vested in the director of lands and survey pursuant to the provisions of Article (16/6) of the Land and Water Settlement Law No. (40) of 1952. If the error is not due to a clerical error, then the court of first instance has jurisdiction over the lawsuit for correcting the name recorded in the land register".

\section{The lawsuit for enforcement of foreign judgments}

The enforcement of foreign judgments issued outside the Hashemite Kingdom of Jordan is vested in the courts of first instance in accordance with Article 3 of the Foreign Judgments Enforcement Law No. (8) of 1952, which provides that: "It is permissible to enforce the foreign judgment in the Hashemite Kingdom of Jordan by filing a suit for such enforcement before a court of first instance." Article 4 of the said Law provides that: "The lawsuit for enforcement a foreign judgment is filed through a request submitted to the court of first instance in which jurisdiction the convict resides or the court within its jurisdiction the property of the convict exists if the convict does not reside in the Hashemite Kingdom of Jordan."

Accordingly, the Court of Cassation ruled that "Article 3 of the Foreign Judgments Enforcement Law No. (8) of 1952 permits enforcement of a foreign judgment in Jordan through bringing an enforcement lawsuit before the court of first instance in which jurisdiction the convict resides or the court within its jurisdiction the property of the convict exists if the convict does not reside in the Kingdom".

Under other legal provisions, the court of first instance, in its civil capacity, has jurisdiction over some lawsuits, including:

1. Compensation for expropriation.

2. Challenging the municipal elections.

3. Writing-off a trade name.

4. Appealing some decisions regarding companies according to Article M / 211 / B of the Jordanian Companies Law.

5. Personal status matters between two parties, a Muslim and a person belonging to a non-Muslim religious community, and also the matters between two non-Muslim parties who do not belong to the same religious community.

Requirement 2: Jurisdiction of the courts of first instance in its appellate capacity

In the Jordanian judicial system, the courts of first instance have jurisdiction as a court of second instance, i.e., in an appellate capacity in accordance with Article 4/b / 2 of the Civil Courts Formation Law, where it provides that " the courts of first instance shall have the right $: b$. in their appellate capacity, to hear 1 . The appeals against appealable judgments issued by the magistrate courts and filed before the courts of first instance 2. An appeal against any judgment that can be appealed before the courts of first instance under any other law".

In accordance with Article 4 of Civil Courts Formation Law, the courts of first instance, in their appellate capacity, have the right to hear appeals against the appealable decisions issued by the enforcement department under the Enforcement Law.

Pursuant to Law No. 30 of 2008 amending the Magistrates Courts Law No. 25 of 1988, Para 2 of 
Article (10/2) of the Magistrate Courts Law provides that: "2 - The Magistrate's Court ruling is final in the civil suits concerning an amount of movable property if the claimed value does not exceed (two hundred and fifty JOD), save premises evacuation suits".

Thus, the rulings issued by the Magistrate Courts in cases whose value equals to or less than two hundred and fifty dinars in value are final and non-appealable. As for cases whose value exceeds such limit, the rulings are appealable before the court of first instance, in their appellate capacity, if the claimed amount does not exceed one thousand JOD, in accordance with Article (10/3) of the Magistrate Courts Law of 2008.

The said Article excludes premises evacuation suits. Obviously, such exclusion deals with the description of judgment, where all judgments in connection with premises evacuation suits are first instance, and they are, therefore, appealable regardless of the value of the case, i.e. annual rental.

Article 5 of the Civil Courts Formation Law No. 17 of 2001 as amended by Law No. 31 of 2008 provides that:

"c. When trying civil, criminal and executive cases in its appellate capacity, the court of first instance sits with two judges.

d. when the court is sit with two judges and more, it is chaired by the president of the court or the senior judge and its decisions are issued unanimously or by majority.

e. if the court is sit with two judges and they have different opinions during trial or when the final decision is delivered, the president of the court shall name a third judge to join the trial from the stage the case has reached and the previous proceedings are read in his presence".
Topic 2: jurisdiction of courts of first instance over the summary matters and challenges to subject-matter jurisdiction.

\section{This topic includes the following two requirements:}

\section{Requirement 1: Challenges to subject-matter jurisdiction}

Article 111 of the Jordanian Civil Procedure Law, as amended by Law No. 31 of 2017, provides that “ challenging jurisdiction of the Court due to lack of jurisdiction or due to the type, value or admissibility of a case it as it has been already adjudicated; or any other challenges related to the public order can be raised at any status of the case and shall be adjudicated by the Court on its own".

Jurisdiction means the type of cases to be heard by each type of courts under the law. The civil courts have jurisdiction over the civil, commercial and administrative cases, the religious courts have jurisdiction over endowment and Muslim personal status cases, and the religious communities council has jurisdiction over the endowment cases of each community.

Furthermore, each special court has jurisdiction over types of cases set out under the law, where customs courts have jurisdiction over all cases arising from the application of the customs law, and the income tax court (tax assessor) has jurisdiction to assess incomes and taxes thereon. Each court has jurisdiction over one or more types of cases, so the jurisdiction is for the type of civil, religious, or special courts, or the jurisdiction of the all courts of Jordan when it comes to international jurisdiction. The subject-matter jurisdiction means the jurisdiction of each court over one or more types of cases.

The subject-matter jurisdiction is material or absolute, where what matters is only the type, nature of subject-matter of the cases, regardless of the plaintiffs or defendants. This jurisdiction focuses on the public order since the cases' 
subject-matter distribution to courts has nothing to do with litigants or their interests. Rather, it depends on organization of the judiciary facility and diversity of its courts as well as the ability of each court to hear certain cases. This is in addition to the dates observed and the procedures followed in each of them in connection with the type of cases over which it has jurisdiction.

In this context, the Egyptian Court of Cassation ruled that" The court's decision to refer the case to the department concerned with examining the cases of foreigners - does not involve a lack of jurisdiction decision, since the formation of departments to hear foreigners' personal status cases falls within the scope of the internal organization of each court of what the General Assembly is concerned with, and it does not relate to the subject-matter jurisdiction".

Whether they have jurisdiction over certain type/s of cases, the courts' subject-matter jurisdiction is associated with the public order, and this means:

a. The litigants may not agree contrary to the provisions of the rules of subject-matter jurisdiction. The litigants may not agree on the Sharia court's jurisdiction over a commercial dispute between them, nor may they agree that the civil courts hear a dispute between them which is a matter of personal status, where such agreement is deemed to be void.

Moreover, litigants may not agree to file a case for movable property division to the court of first instance, nor may they agree to file an appropriation case to the magistrate court, where such agreement is void as well.

When he distributes the jurisdiction between the different types of courts, and when he assigns certain types of cases to each court, the legislator does so for a higher public interest in society.

b. Challenging the subject-matter jurisdiction is made by the court on its own, whether a trial court of court of law. The courts of first and second instance can make such challenges. Further, the court of cassation also has the right to examine the issue of function on its own.

c. The rules of subject-matter jurisdiction may be raised by the litigants or the court in any stage of trial, and this is due to the fact that the judgment is issued by an incompetent court, where such judgment is considered as if it has not been issued.

d. The judgment issued by a court that lacks subject-matter jurisdiction is unenforceable for nullity.

Lack of subject-matter jurisdiction decision is appealable before the court of appeal and then before the court of cassation as it is considered appealable since it settles the dispute.

Requirement 2: the courts of first instance jurisdiction over summary matters

In accordance with Articles 30 and 31 of the Civil Procedure Law, the court of first instance has jurisdiction over the summary matters. Article $30 / 1$ provides that "the summary matters judge, or his delegate, is the president of the court of first instance, and the magistrate judge concerning the cases fall within his power". Article 32 of the Jordanian Civil Procedure Law provides that "On an interim basis, the summary matters judge will examine the claims, without causing any prejudice to the following matters. However, this shall not prevent the trial court to examine such matters if submitted to it on a hierarchical basis:

1- Urgent matters that are under the risk of time lapse without being adjudicated.

2- Considering the applications to appoint an agent or guardian of property or precautionary sequestration; custody or travel ban.

3- A prompt inspection to prove a certain case.

4- Calling for a witness with the fear of not hearing him in a timely manner to 
decide on a subject that has not been submitted to the judiciary yet and it is possible to be submitted to it. All the incurred expenses shall be borne by the requester".

Hence, urgency and interim action are required to establish the subject-matter jurisdiction of summary court.

\section{Urgency:}

The law does not define the urgency requirement; rather it is determined by the jurists and judges. Deciding urgency in a certain matter is at discretion of the summary court to which the suit is filed. It is not controlled by the court of cassation except to the extent that all other rulings are subject to the supervision of the court of cassation in terms of their causation, i.e. the court's determination of urgency is based on reasonable facts.

Also, the urgency is an issue that the court deduces from the nature of the dispute, and the circumstances and facts surrounding it, and it is not an administrative condition that the litigants may agree on. The agreement of the litigants in the contract to consider the dispute that may arise between them an urgent matter, even though it is not, renders such agreement void, and it does not restrict the summary court to which the dispute is submitted, because in such an agreement is a violation of the rules of the subject-matter jurisdiction which constitute part of public order.

The summary judge decides the summary matters on an interim basis without prejudice to the original right. The powers of summary judge include:

\section{Urgent matters that are under the risk of time lapse without being adjudicated:}

The cases for requesting to prove certain facts to be relied on to prove the right to file a lawsuit in the future, such as proving the condition of perishable goods, such as fruit, for a dispute over its type or quantity and to prove a condition of an place in which a fire occurred to verify its cause.

It is permissible for anyone who fears the loss of features of a certain fact, that might become a subject of a dispute before the court, to request the summary judge to inspect such fact.

In said case, the judge may delegate an expert to inspect the fact, and hear witnesses without an oath, and then he must determine a session to hear the litigants' observations on the expert's report and his actions.

2. Calling for a witness with the fear of not hearing him in a timely manner to decide on a subject that has not been submitted to the judiciary yet and it is possible to be submitted to it and all the incurred expenses shall be borne by the requester:

A person who fears not hearing a testimony on subject that has not been submitted to the judiciary yet and it is possible to be submitted to it to request hearing such testimony. Such request is submitted to the summary judge and the expenses incurred in this respect are borne by the requester.

Firstly, the judge examines the necessity that justifies urgency. Such necessity exists if the witness to be heard is suffering from serious disease (that may lead to death) or is going to participate in a war.

\section{Considering the applications to appoint an} agent or guardian of property or precautionary sequestration; custody or travel ban:

The summary court has jurisdiction over a case due to existence of urgency requirements. This includes the suit for guarding movable or immovable property over which there is a dispute or the right in this respect is not proven. This also applies to the guarding suit filed by the owner of movable or immovable property, if he fears, under reasonable grounds, an urgent risk if such 
property remains under possession of a certain person. Another example is the suit filed by a tenant for appointing a guardian for an elevator if the landlord refrains from managing such elevator so that tenants can use it if the landlord is contractually obliged to enable tenants to use such device.

\section{Protective or temporary measure that does not violate the original right or its subject}

If a temporary action is not required, then it does not fall within the summary jurisdiction, as settling the original dispute. Thus, the summary court may not settle the disputed right, not may it deliver its decision as a result of examination of the original right or the litigants' documents.

It is established that the summary judge may examine the subject-matter of dispute and review the related documents not to form a final opinion on which he builds his decision on the temporary action; rather it is a superficial examination to decide whether to accept or refuse summary action. It should be an occasional examination to define the apparent issues that might help reach the point. Otherwise, the summary judge is required to dismiss the matter.

\section{Authenticity of the summary decision before the trial judge}

As long as the summary judge is prevented from going into depth in examining the original right and in reviewing its documents, it is logical that the decision issued in the interim request, which is based on a superficial examination of the papers, is not authentic before the judge when determining subject-matter of the case. In such a case, a judge may issue a decision in such matter that contradicts the direction of summary court.

On the other hand, the urgent decision is authentic before the summary court, provided that the circumstances do not change. If the summary court previously decided to reject a request for an interim action, the same request may not be accepted again as long as there is no change in the circumstances of the dispute or the status of the litigants. However, if the circumstances under which the summary decision was issued changed, then such decision is no longer authentic, and such request may be re-submitted to the summary court.

\section{Characteristics of summary decision}

As explained earlier, the jurisdiction of summary judge to decide on matters that are under the risk of time lapse without being adjudicated exists if: 1. The matter required is an action not determination of the original issue, and 2. There is an urgent case. If the decision is issued, then it is enforceable under the law without guarantee, unless otherwise stated in the decision.

All decisions issued in summary matters are appealable regardless of the court by which they are issued, where Article 176/2 provides that " 2 . The decisions issued in summary matters may be appealed regardless of the court by which such decision are issued, and the court of appeal shall determine the appeal submitted to it under a decision that cannot be appealable before the court of cassation except by a permission by the president of the court of cassation or his delegate".

Topic 3: subject-matter jurisdiction of the court of first instance over the criminal suits

The courts' subject-matter jurisdiction over criminal matters is determined according to the type of crime with which the accused is charged, and according to the amount of the penalty prescribed to it in the Penal Code. According to the Jordanian legislator's plan, the gravity of the crime is determined according to the penalty prescribed to it. If the penalty determined for a crime is criminal, then it is a felony. If the penalty determined for a crime is misdemeanor then it is a misdemeanor, while if it is a discretionary penalty, then the crime is an offense. 
The criminal courts in Jordan are numerous and varied. In principle, the court of first instance has jurisdiction over all crimes that are of the type of felony. However, given the existence of special legislation that vest the authority to examine some types of crimes in other special courts such as the High Criminal Court and the State Security Court, the legislator has replaced the term first instance courts with criminal courts, although they are originally the courts of first instance, where the legislator gave this name to distinguish them from the special criminal courts, so he named them criminal courts as the criminal court of Amman north, for example.

It should be mentioned here that the Jordanian criminal legislator has given each court the jurisdiction over a certain type of crimes. Hence, in terms of subject-matter jurisdiction, courts are divided into two types:

- Civil courts

- Special courts- they have jurisdiction over a certain group of crimes based on their own laws and as the legislator deems appropriate.

Having reviewed the subject-matter jurisdiction of the courts of first instance, it is found that such courts have general power to hear all felonies and misdemeanors that do not fall within jurisdiction of the magistrate courts. Further, some laws have vested jurisdiction over some crimes in the courts of first instance. Accordingly, this topic will deal with the general and special jurisdiction of the courts of first instance in the following two subtopics.

\section{Sub-topic 1: general jurisdiction of courts of first instance}

Article 140 of the Criminal Procedure Law provides that the court of first instance, according to its power, has jurisdiction over all misdemeanors, that do not fall within jurisdiction of magistrate courts, referred to it by the attorneygeneral or his delegate. In its criminal capacity, the court of first instance has jurisdiction over all felonies and the misdemeanors associated with felonies referred to it by the attorney-general upon the indictment.

According to Article 3 of the Magistrate Courts Law No. 23 of 2017 which provides that the court of first instance has jurisdiction over all offenses and misdemeanors that do not fall within jurisdiction of any other courts, all minor misdemeanors whose penalties do not exceed 2year-imprisiomnet are within the jurisdiction of the magistrate courts and if the imprisonment period exceed two years then they fall within jurisdiction of courts of first instance.

In accordance with Article 5 of the Civil Courts Formation Law No. 17 of 2001, as amended, the court of first instance sits with a sole judge when examining misdemeanors that fall within its jurisdiction, and it sits with two judges when examining felonies that are punishable by temporary hard labor or temporary detention for a period of less than 15 years that do not fall within the jurisdiction of the High Criminal Court. Further, the court of first instance sits with three judges when examining felonies punishable by death or life imprisonment or temporary imprisonment a period of no less than fifteen years.

The courts of first instance are deemed to be a court of second instance (appellate capacity), where the decisions issued by the magistrate courts and the enforcement departments are appealable before it.

This is set out in Article 4 of the Civil Courts Formation Law, where it provides that the courts of first instance may, in their appellate capacity, hear the appeals against appealable judgments issued by the magistrate courts and the enforcement departments in accordance with the Enforcement Law of 2007 as amended.

\section{Sub-topic 2: Special Jurisdiction of the Court of First Instance}


The special jurisdiction of court of first instance means the jurisdiction vested in the court of first instance in accordance with special criminal laws regardless of the type of a crime and gravity of penalty. An example of this the first instance court jurisdiction over the economic crimes against the state economic security as provided under Article 6 of the Economic Crimes Law No. 11 of 1993, as amended. The said Article provides that the court of first instance has jurisdiction over the crimes prescribed herein unless they fall under jurisdiction of another court under the law of such court.

Though the court of first instance has jurisdiction over all felonies and misdemeanors that do not fall within jurisdiction of the magistrate court, the special laws have excluded a significant part of jurisdiction of this court and vested it in special courts such as the high criminal court and the state security court, and other special courts, in accordance with the laws of such courts. This constitutes a violation of the general principles in the jurisdiction.

In this regard, researcher suggests that the Jordanian criminal legislator should intervene at the first opportunity available to reconsider or abolish the jurisdiction of these courts and to vest the general jurisdiction over of all crimes in the civil courts (the Court of First Instance and the Magistrate Court) in order to achieve justice, avoid conflicts in the jurisdiction and ensure the proper functioning of justice.

\section{Conclusion:}

This paper concludes that the courts of first instance in the Jordanian judicial system have general jurisdiction over all civil, commercial and criminal suits, including the summary suits, unless a special provision determines a certain jurisdiction for magistrate courts or other bodies.

We argue that the court of first instance has, in its appellate capacity, jurisdiction over some suits prescribed under the law. For example, Article 28 of the Magistrate Courts Law No. 15 of 1952 as amended by the Law No. 13 of 2001 .

It is noticed that under Article 28 of the Magistrate Courts Law, the legislator has reduced powers of the court of first instance, in its appellate capacity, to limits of suits whose value does not exceed 250 JOD.

As to Paragraphs (c and d) of Article 5 of the Civil Courts Formation Law provide that the court of first instance is composed of two judges when examining the civil and criminal suits, we argue that this violate the principle "courts are collegiate in nature "which requires odd and not even number of judges to address different opinions of judges when delivering the final decision.

It is also noticed that in the Jordanian civil Procedure Law No. 14 of 2001 as amended by the Law No. 24 of 1988, the legislator has repealed Article 30 of the Law, which explained the courts of first instance jurisdiction over the suits filed to it in its appellate capacity; we suggest that repealed Article should be restored.

\section{References}

[1] Al-Zubi, Awad, Ahmad, Civil Procedure, $1^{\text {st }}$ volume, $1^{\text {st }}$ edition, Dar Wael for Publication, Amman, 2003.

[2] Al-Araj, Lawyer Musa, Civil Laws Jurisdiction over Non-civil cases, Bar Association Journal, special edition, 2004.

[3] Al-Nemr, Amina, Civil and Commercial Procedure Law, Munshat Al-Maaref, 1st edition, 1987 